\title{
The Potential Role of Water Hyacinth in Wastewater Treatment in Nepal
}

\begin{abstract}
River pollution is one of the significant environmental problems in Nepal. It is primarily due to the direct discharge of sewage from semi-urban and urban areas. The situation is widespread in Kathmandu Valley where the few wastewater treatment facilities are either inefficient or abandoned and modern wastewater treatment facilities are too expensive. The water hyacinth is known as the world's most unwelcomed flora due to its invasive nature. However, numerous studies revealed many beneficial aspects of the plant species. The plants have already been widely used for different purposes like composting, substrate for mushroom farming, nutritious food for cattle, feed for biogas generation, protein synthesis, fibres for furniture, and for wastewater treatment, etc.

This study investigates the possibility of water hyacinths in wastewater treatment in Nepal. Concentration reduction in BOD5, TN, TP, FC were analyzed weekly for four weeks, and the reduction efficiencies compared with systems without water hyacinth. The experiment resulted in a clear reduction of pollutants/nutrients in the water hyacinth treatment system compared to the system without water hyacinth. In addition, the water hyacinth treatment system was able to remove odour and colour completely, which made the system comparatively advantageous over the system without water hyacinth. It will be beneficial to upgrade existing sewage lagoons in Nepal into water hyacinth systems.
\end{abstract}

Key words: Wastewater, water hyacinth, hydraulic retention time, treatment, control, Nepal

\section{Background}

$\mathbf{U}$ rbanization and population growth has put tremendous pressure on rivers of Nepal. While the ever increasing demand for fresh water for domestic purposes is emptying the flowing wetlands and aquifers, huge volumes of wastewater produced in these areas pollute the remaining water in the rivers and other fresh water bodies. The urban areas of Nepal lack effective wastewater treatment systems. Nepal consists of 58 municipalities and is in the process of increasing their numbers, but the wastewater treatment systems installed so far are few. These treatment facilities merely work and most are located inside Kathmandu Valley. Four out of five major wastewater treatment plants in the Kathmandu Valley alone are not fully functional or have been abandoned (Sah 2007a). The only modern wastewater treatment facility (activated sludge type) in Kathmandu Valley, located at Guheshwori, has proven to be inefficient and insufficient to treat the heavy loads of sewage than it was intended for (Sah 2007b). As a result, the rivers remain heavily polluted throughout the year.

The total wastewater treatment demand of Nepal is 370 million litres per day while the total installed capacity can only treat 37 million litres per day, but are working only at half of its capacity (WaterAid 2008). Furthermore, the WaterAid report concludes that the reason behind the underdevelopment of the wastewater treatment system is lack of government willingness because modern wastewater facilities require high installation and maintenance cost, and one facility is not sufficient to solve the problem. For illustration, the installation cost of the modern wastewater treatment facility at Guheshwori, Kathmandu was around US\$ 9 million (US\$ 1.00=NRs. 74.4, at the February 10, 2010 exchange rate) including other developments around the area. The annual operational and maintenance cost is around US\$ 170 thousand (BASP 2007).

Reed Bed Treatment System (RBTS) is a wastewater treatment system that is gradually gaining momentum in Nepal. The first was introduced at the Dhulikhel Hospital, Nepal, in 1997. The system has been replicated at more than a dozen places. According to the WaterAid report, the largest capacity of its type is able to treat 25$40 \mathrm{~m}^{3}$ effluents per day and can serve the population of around 200 households (WaterAid 2008). No doubt, RBTS is highly significant as decentralized wastewater treatment systems. Likewise, upgrading the existing sewage lagoons/facultative ponds with water hyacinth system would be another method to deal with Nepal's wastewater problem.

\section{Water Hyacinth General introduction}

Water hyacinth belongs to the family Pontederiaceae and genus Eichhornia (Gopal 1987). The flower resembles those of the family Liliaceae, genus Hyacinthus; therefore it is called water hyacinth. The mature water hyacinth plant consists of roots, rhizomes, stolons, leaves, inflorescences and fruits clusters (Penfound and Earle 1948).

Biological classification of the common water hyacinth

Kingdom: Plantae

Subkingdom: Tracheobionta

Superdivision: Spermatophyta

Division: Magnoliophyta

Class: Liliopsida

Subclass: Lilidae

Order: Liliales

Family: Pontederiaceae

Genus: Eichhornia

Species: crassipes

Source: (USDA 2010) 


\section{Habitat and distribution}

Water hyacinth grows throughout the tropics and sub-tropics as a free-floating perennial. In temporary water bodies, the plants survive in moist mud and remain anchored to the soil (Gopal 1987). It grows equally well in natural waters and in artificially produced water bodies (Penfound and Earle 1948). The growth is adversely affected by low temperature and completely ceases in freezing cold. For that reason, water hyacinth behaves like a seasonal plant where growth is halted by winter temperatures but enhanced during summer and rainy seasons (Gopal 1987).

\section{Brief history of spread}

The common water hyacinth, E. Crassipes, was first introduced to Europe as ornamental plants in botanical gardens from South America and similarly introduced to the other continents of Asia, Africa, Australia and North America from Europe in the 19th century, during the time of European influence in these continents (Gopal 1987). In India, the plant was first thought to have been introduced in the early 1890 os in Bengal. By 1914, the plant had become a serious problem. It had already proliferated all along the Indian subcontinent by 1947 (Gopal 1987). Nepal shares the border with India. Therefore, it can be expected that water hyacinth made its way to Nepalese water between 1914 and 1947. However, it was first reported in Nepal in 1966 (Dahal 2007).

\section{Usages of water hyacinth}

A wide range of processes and applications has been developed for usages of water hyacinth. According to Jianqing, Ren et al (2001), people now use water hyacinth plants to feed pigs and ducks and to make fertilisers, compared with the situation in 1960. The weed has also received increasing attention as a new resource for paper production, biogas production, and control of water pollution through its use in biological wastewater treatment (Gopal and Trivedy 1984).

One of the projects 'Making Organic Compost' carried out by the Wildfowl and Wetland Trust in Koshi, Nepal, found that water hyacinth compost holds nutrient concentrations comparable to chemical fertilizers and has no significant concentrations of poisonous metals (WWT 2008). The levels of nitrogen, phosphorus, potassium and $\mathrm{pH}$ were acceptable in compost made from water hyacinth (Kafle, Kafle et al 2009).

In addition, Wolverton and McDonald (1979) concluded that a hectare of water hyacinth could produce sufficient biomass to generate approximately $58,400 \mathrm{~m}^{3}$ of biogas containing $35,100 \mathrm{~m}^{3}$ of methane. The estimation was based on the annual productivity of 154 metric tons per hectare grown in a fertile sewage lagoon.

\section{Wastewater treatment ability of water hyacinth Nitrogen and phosphorus}

Three important nutrients for plant growth are carbon, nitrogen and phosphorus (Masters and Ela 2008). Nitrogen and phosphorus are the most important elements when discussing water pollution (Gopal 1987). Wastewater is usually rich in nitrogen and phosphorus and water hyacinth can grow luxuriously in such nutrient rich water environment. Processes like nitrification and denitrification are involved in the removal of nutrients from wastewater under a water hyacinth treatment system.

Rogers and Davis (1972) estimated that absorption by a hectare of water hyacinth amounted to 2,500 kilogram (kg) of nitrogen and $700 \mathrm{~kg}$ of phosphorus per year if maximum growth could be sustained, which is equal to nitrogen and phosphorus released by 800 people in a day.

In the comparative experiment carried out by Orth and Sapkota (1988), Total Kjeldahl Nitrogen or TKN (which is ammonium nitrogen plus organic nitrogen) and Total Phosphorus (TP) were reduced by $73.7 \%$ and $71.4 \%$ respectively in the facultative pond with water hyacinth whereas TKN in the facultative pond without water hyacinth was reduced to $30 \%$ only during the same period and TP reduction was not realized at all.

\section{Biochemical oxygen demand (BOD) and chemical oxygen demand (COD)}

Water hyacinth plants are also known to be successful in the reduction of $\mathrm{BOD}_{5}$ (five days biochemical oxygen demand) in significant quantities from lagoons heavily loaded with organic domestic wastewater (Wolverton and McDonald 1979). When facultative ponds fed by secondary effluent with similar conditions were compared (one with water hyacinth and another without water hyacinth), significant reduction of COD (75\%) from water hyacinth treated secondary effluent were reported by Orth and Sapkota (1988). Based on Adewumi and Ogbiye (2009), a running system of water hyacinth treatment reduced $35 \%$ of BOD and $19.5 \%$ of COD.

\section{Heavy metals}

Water hyacinth has the potential for purifying not only domestic wastewater but also industrial wastewater. It can readily absorb and concentrate heavy metals such as lead, cadmium, mercury, and nickel in high quantity without exhibiting visible signs of toxicity (Wolverton and McDonald 1979). Tissue analysis of plants from different sources reveals that water hyacinth is able to absorb and accumulate a variety of heavy metals such as iron, manganese, zinc, aluminium, cadmium, lead, mercury, nickel, silver, cobalt, strontium, chromium and copper. Even platinum was found in traces (Gopal 1987).

\section{Micro-organisms}

The main source of micro-organisms in sewage is human excreta (Masters and Ela 2008). According to Gopal (1987), the water hyacinth system can possibly be used for decontamination of municipal or domestic wastewater. Based on studies by Adewumi and Ogbive (2009), floating and running reed bed system of water 
hyacinth could reduce $99 \%$ of faecal coliform (FC) and total coliform from raw wastewater. However, the study does not recommend the treated water for either potable or non-potable purpose and recommends disinfection prior to use for any purposes.

\section{Economics of water hyacinth treatment system}

Dinges (1978) has concluded that a water hyacinth system in conjunction with facultative ponds are a potential economic wastewater treatment system that can be constructed and operated in warm places, as the system is run by the natural process like solar energy and the force of gravity. Likewise, Cornwell, Zoltek et al (1977) have concluded that the water hyacinth system would be economical and efficient for the control of eutrophication, where the land is inexpensive and easily available.

\section{Research Objectives}

Our research has investigated the possibility of water hyacinth for domestic wastewater (i.e., meaning raw sewage for the purposes of this study) treatment in Nepal. The specific objectives of the research were to:

a. Examine pollutant/nutrient reduction from domestic wastewater treated by water hyacinth. The following pollutant/nutrient parameters were examined:

- biochemical oxygen demand $\left(\mathrm{BOD}_{5}\right)$

- total nitrogen (TN)

- total phosphorus (TP)

b. Determine whether short-term (four weeks) hydraulic retention time is adequate for reducing pollutants/ nutrients to a level acceptable enough for discharge into inland water.

c. Examine the reduction of $\mathrm{FC}$ in conjunction with nutrient removal in water hyacinth treatment systems.

d. Compare the treatment efficiencies of water hyacinth with a system without water hyacinth. Efficiency is simply defined as percentage reduction of various pollutants/nutrients examined for this study.

\section{Materials and Methods}

This research adopted an experimental approach to examine the performance of water hyacinth in domestic wastewater treatment in Kathmandu, Nepal. The experiment was conducted during May and June. These times are especially favourable for plant growth in Nepal, including water hyacinth.

\section{Experimental set-up}

Six equal sized concrete containers ( $61 \times 58.5 \times 51$ $\mathrm{cm}^{3}$ ) were constructed on the roof top of a two-story house at Nakkhu, Lalitpur, Nepal. These containers were used as a prototype of sewage lagoons (facultative ponds). The effective volume (volume of wastewater) was 146 liters. Out of the six containers, three were assigned as treatment containers and the other three as control containers. Figure 1 shows the experimental set-up. For the study purpose, the researchers adopted 'treatment' and 'control' for identification of containers with and without water hyacinth respectively.

Water hyacinth plants were collected on May 11, 2010, seven days prior to the start of the experiment. The plants were collected from a nearby pond at Balkumari, Lalitpur, Nepal and then cleaned with river water followed by tap water. Thereafter, all the dead leaves and shoots of the plants were trimmed off. The clean plants were then retained in clean water for a week.

Wastewater was collected from one of the major sewers of Lalitpur Sub-Metropolitan City, which drains

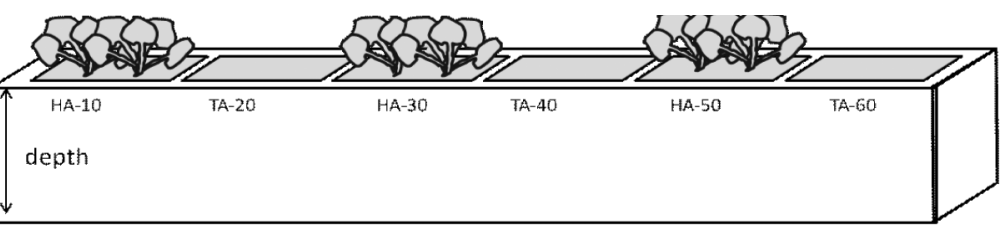

Figure 1. Three Dimensional Views of Experimental Containers.

at Balkumari. A day prior to the initial baseline sampling, the wastewater was collected and transferred into a thousand-liter container.

The wastewater was distributed equally into the experimental containers after the baseline sampling and in-situ analysis. Thereafter, the clean water hyacinth plants, 1.5 kilogram by wet weight, were transferred into all three treatment containers.

The experiment was conducted outdoors on the roof top. Therefore, water loss due to evaporation and evapotranspiration were compensated routinely by deionized water to maintain the water level and control the experiment. The conductivity of the added water was significantly low; $<5$ micro-Siemens per centimeter $(\mu \mathrm{S} /$ $\mathrm{cm})$ compared to the experimented wastewater having conductivity around $1990 \mu \mathrm{S} / \mathrm{cm}$. Therefore, it was assumed that the effect would be insignificant.

\section{Selection of parameters}

Based on the research objective, four parameters were selected as primary parameters for the research: biochemical oxygen demand $\left(\mathrm{BOD}_{5}\right)$, total nitrogen (TN), total phosphorus (TP) and faecal coliform (FC). In addition, a few secondary parameters including temperature, $\mathrm{pH}$, dissolved oxygen, and electric conductivity were analyzed. The secondary parameters were used as indicator parameters for necessary control of the experiment.

\section{Results and Discussion}

Wastewater from treatment and control systems were sampled and analysed for four weeks to find out the pollutants/nutrients and faecal coliform removal capacities of the systems. The experiment was begun with equal baseline values for treatment and control systems. See Table 1 and Figure 2.

The water hyacinth treatment system has reduced $\mathrm{BOD}_{5}$ by $98.22 \%$. The system was able to reduce far 
beyond the WHO and EU standard values of $\mathrm{BOD}_{5}$. Moreover, by two weeks the system had exceeded the WHO value in $\mathrm{BOD}_{5}$ reduction.

The system has reduced TP by $72.79 \%$ in four weeks period. However, it could not meet either the EU and the WHO standards in four weeks of HRT. Likewise, TN was reduced by $83.26 \%$ from the baseline, but the values

\begin{tabular}{|l|l|l|l|l|l|l|}
\hline HRT & Baseline & Week 1 & Week 2 & Week 3 & Week 4 & $\begin{array}{l}\text { EU/WHO } \\
\text { standard* }\end{array}$ \\
\hline BOD (mg/l) & 1037.50 & 195.00 & 70.00 & 43.75 & 18.50 & $(30-100) / 25$ \\
\hline$\%$ reduction (BOD) & 0.00 & 81.20 & 93.25 & 95.78 & 98.22 & \\
\hline TP $(\mathrm{mg} / \mathrm{l})$ & 26.56 & 14.32 & 15.03 & 10.18 & 7.23 & $(1-2) /(0.1-1)$ \\
\hline$\%$ reduction (TP) & 0.00 & 46.07 & 43.42 & 61.66 & 72.79 & \\
\hline TN (mg/l) & 192.95 & 173.64 & 110.85 & 60.15 & 32.30 & $(10-15) / 10$ \\
\hline$\%$ reduction (TN) & 0.00 & 10.01 & 42.55 & 68.83 & 83.26 & \\
\hline FC $\left(10^{6}\right.$ CFU/100ml) & 1.850 & 0.200 & 0.195 & 0.017 & 0.011 & n.a/ $(<1000)$ \\
\hline$\%$ reduction (FC) & 0.000 & 89.19 & 89.46 & 99.09 & 99.39 & \\
\hline * EU standard for urban wastewater treatment effluent and WHO standard for typical treated effluent. & \\
\hline
\end{tabular}

Table 1. Concentration and Percentage Reduction of $\mathrm{BOD}_{5}$, TP, TN \& FC in Water Hyacinth Treatment System

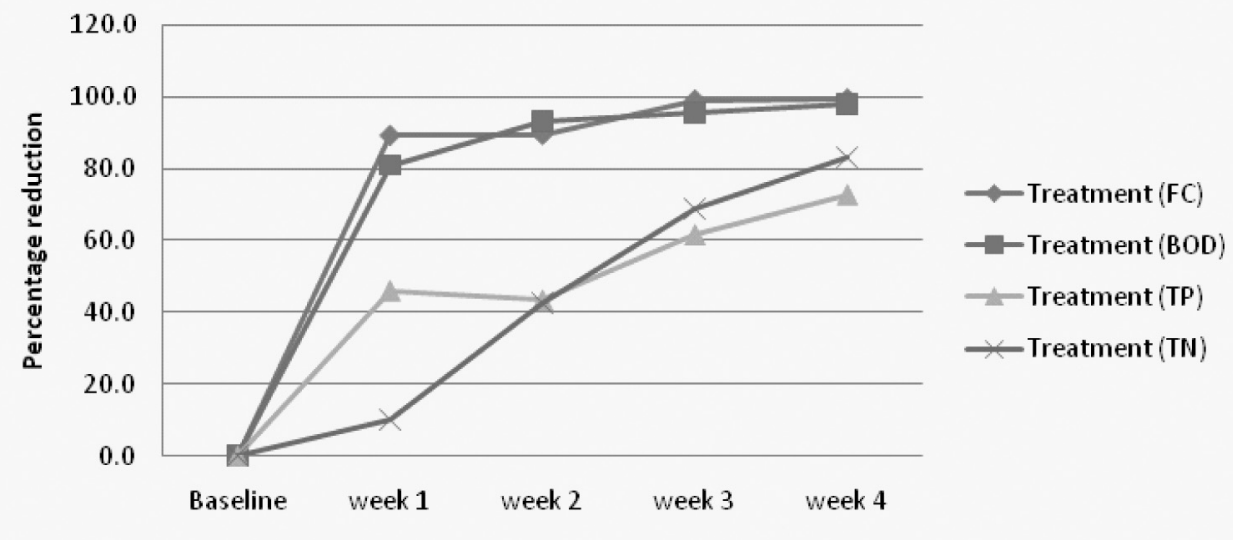

Figure 2. Percentage Reduction of $\mathrm{BOD}_{5}, \mathrm{TP}, \mathrm{TN}$ and FC

were higher than the EU and WHO standards.

It was foreseen that $\mathrm{FC}$ would be reduced due to the reduction in $\mathrm{BOD}_{5}, \mathrm{TN}$ and $\mathrm{TP}$. The result was in the same line: $\mathrm{FC}$ was reduced by $99.39 \%$; i.e., $11,000 \mathrm{CFU} / 100 \mathrm{ml}$. This result is slightly above than WHO guideline value of $<1000 \mathrm{CFU} / 100 \mathrm{ml}$. This indicates that the threat of pathogens in the effluent is still present and may be harmful to human health if discharged to inland water or used for other purposes such as agriculture or fisheries.

When the treatment system is compared with the control system, the treatment system was more efficient than the control system in the reduction of the pollutant/ nutrients and faecal coliform. The treatment system was $6.3 \%$ more efficient than the control system in $\mathrm{BOD}_{5}$ reduction, $19.4 \%$ more efficient in TN reduction, $2.6 \%$ more efficient in TP reduction and $4.4 \%$ more efficient in $\mathrm{FC}$ reduction. It shows that the water hyacinth treatment system has clear advantages over the sewage lagoons (facultative pond), here known as control system.
Nonetheless, the treatment system was still unable to reduce TN, TP and FC to the EU and WHO standards, which indicates the need of additional retention time to reduce $\mathrm{N}$ and $\mathrm{P}$ concentration before discharging into inland water. In the USA, wastewater is usually retained for from 30 to 60 days (Wolverton and McDonald 1979). Another way could be to introduce a primary treatment system before the water hyacinth treatment. Primary treatment or sedimentation can reduce $25 \%$ to $40 \%$ of BOD (Masters and Ela 2008), $10-15 \%$ of nitrogen and $15^{-}$ $20 \%$ of phosphorus from the typical domestic wastewater (Chagnon and Harleman n.d.; Lohani n.d.). In case of FC, chlorination might be the best option to fully decontaminate the effluent before releasing into any surface water body.

Besides the above findings on reduction of pollutants/nutrients and faecal coliform, the following findings are also noteworthy. The temperatureofKathmandu Valley during the course of the experiment ranged between $14^{\circ} \mathrm{C}$ to $33.6^{\circ} \mathrm{C}$ and $\mathrm{pH}$ value of wastewater reached 8.5. Water hyacinth was observed to have grown well under these conditions.

It was found from the experiment that water loss due to evapo-transpiration from the water hyacinth cover was higher than the water loss due to evaporation from the control system over an equal surface area.

The acceptance of people for water use primarily depends on the color and odor. The blackish color and overpowering odor of wastewater turned colorless and odorless in the treatment system during the final sampling. The water in the control containers remained brownish and opaque and retained a faint odor. Moreover, the control system was plagued by algal blooms, whereas it was observed that water hyacinth completely checked the growth of algae in treatment system.

\section{Conclusions and Recommendations}

The experiment showed that the water hyacinth treatment system is efficient compared to the system without water hyacinth reducing the pollutants/ nutrients and faecal coliform. In addition, the former has numerous advantages over the control system. Firstly, 
upgrading the sewage lagoons (facultative ponds) with water hyacinth is beneficial, because it removes odor and makes the water visually transparent and aesthetically acceptable. Secondly, water hyacinth can be used to control algal blooms in nutrient rich water. However, the system provides an environment for mosquito breeding and development. Mosquito breeding can be controlled by introducing Gambusia affinis (mosquito fish), if DO (dissolved oxygen) of the wastewater could be kept at a level sufficient for fish survival (Li, Hao and Zhu 2000).

The water hyacinth system can make a difference to domestic wastewater treatment in Nepal. Domestic wastewater is currently discharged directly into the rivers, causing extreme river pollution. Unwillingness of government and financial constraint are the major reasons behind underinvestment in the wastewater sector. Besides these problems, the existing large lagoons constructed for wastewater treatment purposes are abandoned and the lagoons invaded by water hyacinth and other aquatic plants. Water hyacinth systems may not be the long term and complete solution, but the system can be the nearest alternative for Nepal while waiting for modern facilities. When modern facilities are introduced, the water hyacinth treatment system can be integrated for tertiary treatment or effluent polishing, because it is inexpensive.

Furthermore, water hyacinth treatment system can be promising in Nepal for domestic wastewater treatment if the following socio-economic values can be added to the system. The system can be used as the source of biomass for biogas production; the regular harvest of water hyacinth can be used as feed for biogas digester. Alternatively, utilizing the plants' high nutrient content property, the plants can be used for mushroom farming and composting. Nevertheless, it is highly recommended to conduct an experiment under natural condition for at least a full year before implementing the system.

Ram Bahadur Singh Maharjan is a free lance environmentalist, a graduate from the National University of Singapore in Environmental Management (2011) and from Tribhuvan University in Sociology (2005). He has worked as a program officer for Kathmandu Participatory River Monitoring Project (2006-2008) and Human Values-Based Water Sanitation and Hygiene Education Project (2008-2009) in ECCA-Nepal. He was also an UN Volunteer for UNHabitat as WASH Specialist (2010/2011).

Corresponding address: zeeramcha@yahoo.com

Dr. Chou Loke Ming is a Professor with the National University of Singapore (NUS), Department of Biological Sciences. He is a marine biologist and has been associated with NUS since 1977. He was Visiting Professor at Yale University in 2007 and at Waseda University in 2010 and 2011. He is a member of the
Scientific and Technical Advisory Committee of the Global Coral Reef Monitoring Network and an Executive Board Member of Asia Environmental Council. His main research interests are in coral reef biology and management, and climate change impacts on Southeast Asia's marine biodiversity.

Corresponding address: dbsclm@nus.edu.sg

\section{References}

Adewumi, I. and A. S. Ogbiye, 2009, 'Using water hyacinth (Eichhornia crassipes) to treat wastewater of a residential institution', Toxicological and Environmental Chemistry 91(5):891-903.

Chagnon, F. and D.R. Harleman, n.d., 'An Introduction to Chemically Enhanced Primary Treatment'; URL: $\quad$ www.fastonline.org/CD3WD_40/ASDB_ SMARTSAN/Introduction_to_CEPT.pdf

Cornwell, D.A., J. Zoltek, D.C. Patrinely, T.D. Furman and J. Kim, 1977, 'Nutrient Removal by Water Hyacinths,' Journal of the Water Pollution Control Federation 49(1):57-65.

Dahal, B.R., 2007, 'Effects of water hyacinth Eichhornia crassipes on aquatic birds at Koshi Tappu Wildlife Reserve, south-east Nepal, Danphe (Kathmandu) 16(1):64-65;URL:www.birdlifenepal.org/newsletter/ danphe_special_march_07.pdf.

Dinges, R., 1978, 'Upgrading stabilization pond effluent by water hyacinth culture', Journal of Water Pollution Control Federation 50(5):833-845.

BASP, 2007, An Introdution: High Powered Committee for Implementation and Monitoring of Bagmati Area Sewerage Construction/Rehabilitation Project, Kathmandu: Bagmati Area Sewerage Construction/ Rehabilitation Project, Government of Nepal.

Gopal, B. and R.K. Trivedy, 1984, 'Influence of water hyacinth cover on thephysico-chemical characteristics of water and phytoplankton composition in a reservior near Jaipur (India)', Internationale Revue der gesamten Hydrobiologie und Hydrographie 69(6):859-865.865.

Gopal, B., 1987, Water Hyacinth, New York: Elsevier Science Publisher B.V.

Jianqing, D., W. Ren, F. Weidong and Z. Guoliang, 2001, 'Water hyacinth in China: Its distribution, problems and control status', pp.29-32 in M. Julien, M. Hill, T. Center and D. Jianqing (eds.), Biological and Integrated Control of Water hyacinth, Eichhornia crassipes, Canberra: Australian Centre for International Agricultural Research.

Kafle, M.R., G. Kafle, M.K. Balla and L. Dhakal, 2009, 'Results of an Experiment of Preparing Compost from Invasive Water hyacinth (Eichhornia crassipes) in Rupa Lake Area, Nepal', Journal of Wetlands Ecology 2(1\&2):17-19.

Li, X.Z., X. Hao and D.Y. Zhu, 2000, 'A modified aeration for promoting neutrients removal using water hyacinth to treat sewage,' Environmental Technology 21(5):525-534. 
Lohani, S., n.d., Water Pollution \& Waste water Treatment, Australia: University of Technology Sydney (UTS).

Masters, G.M. and W.P. Ela, 2008, Introduction to Environmental Engineering and Science, New Jersy: Pearsons Education, Inc.

Orth, H. and D. Sapkota, 1988, 'Upgrading facultative pond by implanting water hyacinth,' Water Research 22(12):1503-1511.

Penfound, W.T. and T.T. Earle, 1948, 'The biology of the water hyacinth,' Ecological Monographs 18(4):447-472.

Rogers, H.H. and D.E. Davis, 1972, 'Nutrient removal by waterhyacinth.' Weed Science 20(5):423-428.

Sah, R.C., 2007a, Efficiency of Guheshwary Waste Water Treatment plant and Compliance Monitoring of Wool Dying and Processing Industries in Kathmandu. Kathmandu: Environment Law Alliance Worldwide (ELAW).

Sah, R.C., 2007b, Legal Analysis and Recommendations:
A Study of Water Related Acts, Regulations, Policy and Programmes, Kathmandu: Kathmandu Participatory River monitoring (KAPRIMO).

USDA, 2010, Classification for Kingdom Plantae Down to Species Eichhornia crassipes (Mart.) Solms, Washington DC: US Department of Agriculture, Natural Resource Coinservation Service; URL: plants. usda.gov/java/ClassificationServlet? source=display \&classid=EICR. (Retrieved October 27, 2010.)

WaterAid, 2008, Decentralized Wastewater Management Using Constructed Wetlands in Nepal, Kathmandu: WaterAid.

Wolverton, B.C. and R.C. McDonald, 1979, 'The water hyacinth: From prolific pest to potential provider', Ambio 8(1):2-9.

WWT, 2008, Making Organic Compost, Slimbridge, Gloucestershire: Wildfowl and Wetlands Trust; URL: http://www.wwt.org.uk.

\section{CALENDAR OF EVENTS - WATER RESOURCES/TUNNELING}

6-7 February, 2012: Workshop on Glacier, Snowmelt and Runoff in the Himalaya, Location Kathmandu, Nepal. Organized by ICIMOD. More Info: www. icimod.org.

20-21 February, 2012: ITA Training Programme: Health and Safety in Tunnel and Underground Construction. Location: New Delhi, India. More info: www.cbip.org.

22-24 February, 2012: Tunnelling Asia' 2012: Challenges and Risk Management in Underground Construction. Location: New Delhi, India. More info: www.cbip.org.

21-22 February, 2012: River Hydrology and Hydraulic (Training), Location: Wallingford, UK. Contact Email: m.brunsdon@hrwallingford.com.

23-24 February, 2012: Flood and Risk Management (Training), Location: Wallingford, UK. Contact Email: m.brunsdon@hrwallingford.com.

7-8 March, 2012: 7th Annual Private Equity Southeast Asia Summit. Location: Marina Mandarin, Singapore. Contact Email: enquiry@iqpc.com.sg. More info: http://www.private-equityseasia.com.

8-9 March, 2012: Dresden Conference on Hydraulic Engineering sponsored by Technische Uuiversitat Dresden. Location: Dresden, Germany. More info: www.iwd.tu-dresden.de.

14-15 March, 2012: International Conference on "Water, Energy, Environment and Food nexus: Solutions and Adaptation under changing climate". Location: Punjab, Pakistan. More info: www.cewre. edu.pk/Conference2012.htm.

26-27 March, 2012: 4th International Conference on Water Resources and Renewable Energy Development in Asia. Location: Shangri-La Hotel, Chiang Mai, Thailand. More info: www. hydropower-dams.com/asia-2012.php?c_id $=89$.

16-22 April, 2012: The Sixth International Conference on Community- Based Adaptation (CBA6). Location: Hanoi, Vietnam. More info: www.ccafs.cgiar.org/events.

13-18 May, 2012: World Congress on Water, Climate and Energy 2012. Location: Dublin, Ireland. More info: www.iwa-wcedublin.org.

28 May 2012 to 2 June, 2012: BALWOIS 2012 Fifth International Scientific Conference on Water, Climate, and Environment Ohrid, Macedonia, http://www.balwois.com/2012.

5 June 2012, International Symposium on Dams for a Changing World, Location: Kyoto International Conference Center, Kyoto, Japan. More Info: www. biztradeshows.com/conferences/symposium-ondams/.

5-8 June, 2012: ECWATECH-2012: International Water Forum. Location: Moscow, Russian Federation. More info: www.ecwatech.com.

5-8 June, 2012: Earth, Wind and Water - Elements of Life. Location: Banff, Alberta, Canada. More info: www.elements2012.ca/default.htm.

24-27 September, 2012: 3rd International Interdisciplinary conference on Predictions for Hydrology, Ecology and Water Resources Management:Water ResourcesandChanging Global Environment. Location: Vienna, Austria. More Info: www.web.natur.cuni.cz/hydropredict2012/. 